\title{
Pembinaan Pegawai Negeri Sipil Di Dinas Pendidikan Dan Kebudayaan Kabupaten Lima Puluh Kota
}

\author{
Resi Rahmadini ${ }^{1}$, Ermita ${ }^{2}$, Nellitawati ${ }^{3}$, Jasrial ${ }^{4}$ \\ 1,2,3,4 Administrasi Pendidikan, Universitas Negeri Padang \\ Resi Rahmadini ${ }^{1}$, e-mail : rahmadiniresi2@gmail.com \\ Ermita ${ }^{2}$, e-mail : ermita@ fip.unp.ac.id \\ Nellitawati ${ }^{3}$, e-mail : nellitawati@fip.unp.ac.id \\ Jasrial $^{4}$, e-mail : jasrial36@gmail.com
}

\begin{abstract}
The points of this study are to obtain data and information regarding the development of civil servants in the education and cultural offices of fifty cities, namely (1) Knowledge Development, (2) Attitude Development, (3) Activity motivation renewal, (4) Activity environment renewal, (5) skills renewal. a descriptive study of a quantitative approach. The study population numbered 85 employees and the sample size was determined using the Taro Yamane formula by means of Proportional Random Sampling of 54 employees. The study instrument was a Likert scale model questionnaire. The results of data analysis show that the development of civil servants in the Education and Culture Office of Fifty Cities Regency has been considered good with the acquisition level of 3.60 with the following explanation; (1) knowledge development has an effect on the good category, namely the achievement of 4.13 , (2) the development of attitude influences the good category is obtained 3.74, (3) the development of morale has an effect on a sufficient level, namely 3.26, (4) work discipline coaching has an effect on a good level, namely on the acquisition of 4.03, (5) skills development is at a sufficient level, namely at the acquisition of 2.86. In general, it can be concluded that the development of civil servants at the Education and Culture Office of Fifty Cities is in the good category with an average score of 3.60. However, the coaching must be optimized again for optimal work results.
\end{abstract}

\begin{abstract}
Abstrak
Poin studi ini yaitu memperoleh data dan informasi mengenai pembinaan pegawai negeri sipil di disdikbud kabupaten 50 kota, yakni (1) Pembinaan Pengetahuan, (2) Pembinaan Sikap, (3) pembaharuan motivasi kegiatan, (4) pembaharuan lingkungan kegiatan, (5) pembaharuan keterampilan. studi bersifat deskriptif atas ancangan kuantitatif. Populasi studi berjumlah 85 pegawai dan besar sampel ditentukan dengan memakai rumus Taro yamane dengan cara Proporsional Random Sampling sejumlah 54 pegawai. Instrumen studi adalah angket model skala likert. Hasil analisis data menunjukkan bahwa pembinaan aparat sipil di disdikbud kabupaten 50 kota telah terhitung baik atas taraf perolehan 3,60 dengan penjelasan sebagai berikut; (1) pembinaan pengetahuan berpengaruh atas kategori baik yaitu di capaian 4,13, (2) pembinaan sikap berpengaruh kepada kategori baik adalah diperoleh 3,74, (3) pembinaan semangat kerja berpengaruh pada taraf cukup yaitu diperoleh 3,26, (4) pembinaan disiplin kerja berpengaruh pada taraf baik yaitu pada perolehan 4,03, (5) pembinaan keterampilan berada pada taraf cukup yaitu pada perolehan 2,86. Secara umum dapat disimpulkan Pembinaan aparat sipil di disdikbud kabupaten 50 kota termasuk kategori baik sama skor rata-rata 3,60. Namun Pembinaan tersebut harus dioptimalkan lagi untuk hasil kerja yang optimal.
\end{abstract}

Kata Kunci: Pembinaan Pegawai

How to Cite: Rahmadini, Resi 1, Ermita 2, Nellitawati 3, Jasrial 4. 2021. Pembinaan Pegawai Negeri Sipil pada disdikbud kabupaten 50 kota. Journal Educational Administration and Leadership, Vol (N): pp. XX-XX, DOI: 10.24036/XXXXXXXXXX-X-XX 


\section{Pendahuluan}

Institusi melambangkan suatu kekerabatan sistematis nan mengatur jalan suatu kerumunan orang untuk menjangkau tujuan khusus. Keberhasilan suatu organisasi di dalam menjangkau maksud yang telah dipermanenkan sangat dipengaruhi oleh kemampuan karyawan selama melaksanakan tugas pekerjaannya. Hal yang perlu berpartisipasi dalam prosedur pada suatu instansi yaitu sumber daya manusia atau karyawan. Dalam melahirkan perilaku aktivitas pekerja yang elok, diharuskan bermacam-macam cara yang dapat dilaksanakan sama pimpinan suatu instansi, yaitu dengan melaksanakan pembinaan kepada karyawan.

Pegawai merupakan perencana, pelaksana, pengawas, dan pengevaluasi semua kegiatan. Semua itu dilakukan dengan ilmu dan pengetahuan yang mereka miliki dalam pekerjaan yang didudukinya. Pimpinan seharusnya dapat membaca situasi jika ada pegawainya yang masih kurang pemahamannya dalam pekerjaannya. Zaman dan teknologi menuntut organisasi memperbarui semua pekerjaan agar lebih efektif dan efisien. Namun tidak semua pegawai bisa menerima hal-hal baru. Oleh akibat itu mesti adanya pembinaan yang akurat sasaran agar pegawai dapat memperluas ilmu dan pengetahuannya dan organisasi dapat makin berhasil dan berdaya guna dalam menjangkau tujuannya.

Pembinaan merupakan salah satu kegiatan dalam manajemen personalia atau kepegawaian, dimana dalam manajemen ini setiap pimpinan harus berusaha optimal untuk menyelesaikan tugas. Pembinaan menurut Thoha (dalam Ermita 2002:7) adalah suatu proses untuk meningkatkan hasil atau pernyataan menjadi lebih baik seperti adanya perubahan, kemajuan, peningkatan, pertumbuhan, evaluasi atau berbagai kemungkinan atas sesuatu kegiatan yang dilaksanakan. Pembinaan merupakan salah satu kegiatan dalam manajemen personalia atau kepegawaian, dimana dalam manajemen ini setiap pimpinan harus berusaha optimal untuk menyelesaikan tugas.

Pembinaan adalah usaha atau tindakan yang dilaksanakan dalam rangka mendapat hasil yang lebih sempurna melalui satu kegiatan baik itu berupa bimbingan, pengarahan dan pengawasan. Pada hakikatnya perbaikan pekerja itu melambangkan satu aksi yang digerakan untuk kesuksesan, penambahan atau koreksi atas materi. Pembinaan pegawai itu penting. Pentingnya pembinaan ini menjamin bahwa segala sesuatu akan terlaksana sinkron dengan agenda dan arahan yang ingin diraih akan terwujud seperti yang diharapkan.

Berdasarkan pengamatan penulis selama tiga bulan pada tanggal 9 desember 2019 - 15 februari 2020 di lembaga organisasi selama melaksanakan praktek lapangan manajemen pendidikan, masih tampak sejumlah pegawai belum mendapat pembinaan dengan tepat. Studi tersebut terpandang sejak adanya masalah yaitu:

1. Adanya setengah pekerja nan rendahnya ilmu untuk melaksanakan pekerjaannya, hingga pekerjaannya kurang maksimal. Dengan itu tidak siap sedia penanggulangan dari pimpinan terhadap persoalan tertera.

2. Masih ada sebagian pegawai terlihat dari sikapnya yang kurang ramah dan bersahabat dengan pegawai lainnya di kantor, dan atasan tidak menegur serta tidak mengarahkan pegawai yang bersangkutan.

3. Masih ada sebagian pegawai kurang bersemangat dalam melaksanakan tugas, dapat dilihat dari pegawai yang malas, tidak antusias, dan tidak giat dalam mengerjakan tugas, sementara atasan tidak memberikan motivasi terhadap pegawai tersebut.

4. Sebagian pegawai masih rendah kedisiplinan nya dalam penyelesaian tugas, dimana tugas dan hasil pekerjaan belum diselesaikan sepenuhnya secara tepat waktu, serta sebagian pekerja lagi terlihat tiba kesiangan dengan kembali duluan, Dengan itu tidak ditegur oleh atasan atau tidak pula diperingatkan.

5. Adanya sebagian pekerja nan tidak terampil paham melaksanakan pekerjaan nan tidak sinkron antara indikasi aktivitas nan sudah ditetapkan dengan pimpinan tidak menyodorkan ajaran

Studi ini bermaksud untuk memperoleh penjelasan tentang : (1) seberapa baik pembinaan pengetahuan pegawai di disdikbud kabupaten 50 kota?, (2) seberapa baik pembinaan sikap pegawai di disdikbud kabupaten 50 kota? (3) seberapa baik pembinaan semangat tugas pekerja di disdikbud kabupaten 50 kota? (4) seberapa baik pembinaan tugas pekerja disdikbud kabupaten 50 kota?, (5) seberapa baik pembinaan keterampilan pekerja disdikbud kabupaten 50 kota?. 


\section{Metode Penelitian}

Jenis studi adalah studi deskriptif menurut Arikunto (2014:3). Populasinya yaitu merupakan pegawai di disdikbud kabupaten 50 kota berjumlah 85 orang. Sampel penelitian 54 diterangkan dengan formula dari taro yamane atau slovin. Jenis data penelitian adalah data kuantitatif, dimana sumber data yaitu pegawai di disdikbud kabupaten 50 kota yang terpilih menjadi sampel. Instrumen studi ini adalah angket skala likert serta 5 pilihan jawaban setelah diuji validitas dan reliabilitas. Teknik analisa data yaitu menggunakan angket dengan memberi skor masing-masing jawaban. Untuk jawaban Selalu $(\mathrm{SL})=5$, Sering $(\mathrm{SR})=4$, Kadang-kadang $(\mathrm{KD})=3$, Jarang $(\mathrm{JR})=2$, Tidak Pernah $(\mathrm{TP})=1$. Klasifikasi dan tabulasi data, yaitu mengelompokkan data yang telah diverifikasi kedalam tabel. Menghitung rata-rata jawaban responden dengan rumus rata-rata atau Mean yang kemukakan oleh Arikunto (2010:284).

\section{Hasil dan Pembahasan}

3.1. Hasil

Berlandaskan produk mulai pengolahan data penulis tentang pembinaan pengetahuan pegawai di disdikbud kabupaten 50 kota dengan rata-rata 4,13 kategori baik. Pembinaan sikap pekerja disdikbud kabupaten 50 kota pada rata-rata 3,74 kategori baik. Pembinaan semangat tugas pekerja disdikbud kabupaten 50 kota pada nilai 3,26 kategori cukup baik. Pembinaan disiplin aktivitas pekerja disdikbud kabupaten 50 kota diberi rata-rata 4,03 kategori baik. Pembinaan keterampilan pekerja disdikbud kabupaten 50 kota diberi rata-rata 2,86 kategori cukup baik.

Tabel 1

Rekapitulasi skor rata-rata Pembinaan Aparat Sipil di Disdikbud Kabupaten 50 Kota

\begin{tabular}{|c|l|c|c|}
\hline No & \multicolumn{1}{|c|}{ Indikator } & Skor Rata-rata & Keterangan \\
\hline 1 & Pengetahuan & 4,13 & Baik \\
\hline 2 & Sikap & 3,74 & Baik \\
\hline 3 & Semangat Kerja & 3,26 & Cukup \\
\hline 4 & Disiplin Kerja & 4,03 & Baik \\
\hline 5 & Keterampilan & 2,86 & Cukup \\
\hline \multicolumn{2}{r|}{ Rata-rata } & 3,60 & Baik \\
\hline
\end{tabular}

\subsection{Pembahasan}

Pembahasan hasil penelitian tentang pembinaan aparat sipil di disdikbud kabupaten 50 kota dilihat bermula indikator pengetahuan, sikap, semangat kerja, disiplin kerja dan keterampilan. Pembahasan hasil penelitian menunjukkan pembinaan pegawai dilihat dari a pengetahuan dimana skor rata-rata terendah yaitu pimpinan mengikutsertakan pegawai dalam pelatihan untuk meningkatkan prestasi kerjanya dengan diperoleh rata-rata 3,20 kategori cukup baik. Menurut Reber (2010) pengetahuan adalah kumpulan informasi yang dimiliki oleh seseorang atau kelompok, budaya tertentu.

Kemungkinan penyebab rendahnya skor rata-rata pada item pimpinan mengikutsertakan pegawai dalam pelatihan untuk meningkatkan prestasi kerja tersebut dikarenakan pimpinan kurang melakukan pengawasan dan tidak meratanya pengikutsertaan pegawai yang akan mengikuti pelatihan tersebut. Solusi yang dapat dilakukan pimpinan dalam mengatasi permasalahan tersebut adalah melakukan fungsi menajemen secara keseluruhan mulai dari perencanaan sampai pada tahap evaluasi, apabila suatu kegiatan sudah dilakukan alangkah lebih baiknya seorang pemimpin melakukan evaluasi dan penilaian terhadap kegiatan yang telah terlaksana.

Jadi untuk meningkatkan indikator pengetahuan menjadi kategori baik maupun sangat baik. Pimpinan harus melakukan fungsi manajemen dengan efektif mulai dari perencanaan sampai pada evaluasi/pengawasan terhadap pegawainya serta memberikan dorongan/motivasi terhadap karyawannya.. Sehingga dapat tercipta suatu aktivitas yang berkaitan erat dengan penentuan atau evaluasi mengenai sejauhmana pelaksanaan kerja sudah dilaksanakan. 
Pembahasan hasil penelitian menunjukkan pembinaan pegawai dilihat dari aspek sikap di disdikbud kabupaten 50 kota beserta skor rata-rata terendah yaitu pimpinan memotivasi pegawai agar memberikan pelayanan terbaik terhadap setiap orang yang berurusan dengannya yaitu memperoleh rata-rata 3,03 dalam kategori cukup baik. Saifudin Azwar (2010: 3) sikap diartikan sebagai suatu reaksi atau respon yang muncul dari seseorang individu terhadap objek yang kemudian memunculkan perilaku individu terhadap objek tersebut dengan cara-cara tertentu.

Kemungkinan penyebab rendahnya skor rata-rata pada item pimpinan memotivasi pegawai agar memberikan pelayanan terbaik terhadap setiap orang yang berurusan dengannya tersebut adalah kurang tampak dari pimpinan menegaskan kepada pegawai dalam melayani orang yang berurusan dengannya, sehingga masih ada sebagian pegawai yang kurang melakukan pelayanan terbaik yang mengakibatkan orang yang berurusan dengannya menjadi tidak nyaman. Sikap biasanya terdapat dari pribadi individu itu sendiri. Sikap menggambarkan suatu anggapan, kehendak dan penilaian orang untuk memahami arahan tertentu pada wilayah yang acap kali bersifat stabil karena susah dirubah.

Jadi untuk meningkatkan indikator Sikap menjadi kategori sangat baik maka untuk mencapai daya guna dan hasil kerja yang baik dalam suatu instansi diperlukan sikap yang baik pula dari para pegawai nya terlebih dahulu. Melalui pelaksanaan sikap tersebut diharapkan para pegawai dapat menjaga attitude nya sehingga di dalam instansi terjalin keharmonisan.

Pembahasan hasil penelitian menunjukkan pembinaan pegawai dilihat dari aspek semangat kerja di disdikbud kabupaten 50 kota skor rata-rata terendah adalah pimpinan menyemangati pegawai dalam melaksanakan pekerjaan yang baik dan pimpinan memantau tingkat keberhasilan dari semua tugas yang telah pegawai kerjakan diperoleh nilai 3,05 dengan kategori cukup baik. Menurut Hasibuan (2010:143) Semangat kerja adalah suatu kondisi orang dalam melakukan pekerjaannya dengan giat dan lebih baik dalam sebuah organisasi. Dimana pegawai dalam sebuah organisasi harus mempunyai semangat kerja dalam melaksanakan pekerjaannya agar tujuan instansi tercapai.

Kemungkinan penyebab rendahnya skor rata-rata pada item pimpinan menyemangati pegawai dalam melaksanakan pekerjaan yang baik dan pimpinan memantau tingkat keberhasilan dari semua tugas yang telah pegawai kerjakan tersebut adalah pimpinan yang terlalu sibuk sehingga kurang memberikan semangat untuk pegawai dalam melaksanakan tugasnya. dan juga pimpinan kurang pengawasan terhadap tingkat keberhasilan tugas yang telah pegawai kerjakan. Jadi untuk meningkatkan indikator semangat kerja menjadi kategori baik pimpinan dapat meningkatkan lagi serta diperhatikan setiap perkembangan pekerjaan yang dilakukan oleh pegawai.

Pembahasan hasil penelitian menunjukkan pembinaan pegawai dilihat dari aspek disiplin kerja di disdikbud kabupaten 50 kota beserta skor rata rata terendah adalah pimpinan memberikan sanksi yang tegas jika pegawai melampaui tata tertib yang telah diaturkan dalam mengerjakan pekerjaan diperoleh rata-rata 3,87 dengan kategori baik. Hasibuan (2016: 115) mengemukakan bahwa disiplin kerja adalah kesadaran dan kesediaan seseorang dalam mentaati semua peraturan perusahaan dan norma-norma sosial yang berlaku.

Kemungkinan penyebab rendahnya skor rata-rata pada item pimpinan memberikan sanksi yang tegas jika pegawai melampaui tata tertib yang telah diaturkan dalam mengerjakan pekerjaan karena pimpinan yang kurang tegas dalam memberlakukan sanksi mengakibatkan pegawai lalai dalam melaksanakan tugas. Pembinaan disiplin kerja sangat penting dilakukan dalam usaha menjamin terpeliharanya tata tertib yg telah ditetapkan oleh penguasa negeri kepada pegawai, sehingga kinerja pegawai dapat berjalan lancar dan efektif.

Jadi untuk meningkatkan indikator disiplin kerja menjadi kategori sangat baik pembinaan disiplin kerja oleh pimpinan kepada pegawai yang berdisiplin akan melaksanakan tugasnya dengan sebaik-baiknya sesuai aturan dan waktu yang telah ditentukan. Pegawai yang disiplin sangat menghargai peraturan dan taat dalam melaksanakan tugasnya. Kunci dari disiplin yang efektif yaitu berkomunikasi dengan kebijakan yang sudah ada sejak awal.

Pembahasan hasil penelitian menunjukkan pembinaan pegawai dilihat dari aspek keterampilan di disdikbud kabupaten 50 kota dengan skor rata rata terendah yaitu pimpinan memberikan pelatihan bagi pegawai untuk mampu menggunakan komputer dalam melaksanakan tugas diperoleh rata-rata 
2,50 pada kategori kurang baik. Menurut, Wibowo (2007:88) menyatakan bahwa keterampilan adalah kemampuan mengerjakan tugas fisik atau mental tertentu, kompetensi mental atau keterampilan kognitif termasuk berfikir analitis dan konseptual.

Kemungkinan penyebab rendah nya skor rata-rata pada item pimpinan memberikan pelatihan bagi pegawai untuk mampu menggunakan komputer dalam melaksanakan tugas disebabkan pelatihan menggunakan komputer tersebut tidak dilaksanakan secara rutin, dan pimpinan yang terlalu sibuk sehingga kurangnya pengawasan pimpinan dalam memperhatikan pemberian pelatihan komputer tersebut. Keterampilan itu sendiri yakni kapasitas orang dalam menerapkan pengetahuan dalam sikap aksi yang berlebih memakai bagian komponen bagian mulai atas faktor lain sebagai pelengkap dalam bekerja tanpa menggunakan kemampuan otak tetapi menggunakan kemampuan fisik.

Jadi untuk meningkatkan indikator keterampilan menjadi kategori baik pembinaan keterampilan oleh pimpinan diharapkan pegawai agar lebih kreatif dalam mengemukakan ide/gagasan sehingga hasil kerja lebih maksimal.

\section{Kesimpulan}

Berdasarkan hasil Penelitian tentang Pembinaan aparat sipil di disdikbud kabupaten 50 kota dapat diambil Kesimpulan: Pembinaan pegawai di disdikbud kabupaten 50 kota dilihat aspek pembinaan pengetahuan sudah baik dengan skor rata-rata 4,13. Pembinaan pegawai di disdikbud kabupaten 50 kota dilihat aspek pembinaan Sikap sudah bagus pada jumlah nilai 3,74. Pembinaan pegawai di disdikbud kabupaten 50 kota dilihat aspek pembinaan semangat kerja sudah cukup baik dengan skor 3,26. Pembinaan pegawai di disdikbud kabupaten 50 kota dilihat aspek pembinaan keahlian tugas telah bagus atas jumlah rata-nilai 4,03. Pembinaan pegawai di disdikbud kabupaten 50 kota dilihat aspek pembinaan keterampilan sudah layak bagus jumlah nilai 2,86. Hasil keseluruhan Pembinaan Pegawai Negeri Sipil di disdikbud kabupaten 50 kota sudah terlaksana baik, Hal ini diamati dari jumlah nilai 3,60.

\section{Daftar Rujukan}

Arikunto, S. (2014). Prosedur Penelitian Suatu Pendekatan Praktik. Rineka Cipta.

Azwar, S. 2010. Sikap Manusia Teori dan Pengukurannya. Yogyakarta: Pustaka Pelajar.

Hasibuan, S.P Melayu. 2010. Organisasi dan Motivasi. Jakarta: Bumi Aksara

Hasibuan, Malayu S.P. 2016. Manajemen Sumber Daya Manusia. Edisi Revisi. Jakarta: Penerbit PT Bumi Aksara.

Reber, S.A., Reber, S.E. (2010). Kamus Psikologi. Yogyakarta: Pustaka Pelajar.

Wibowo. 2007. Manajemen Kinerja. Jakarta: PT. Raja Grafindo Persada 